\title{
Nominal Representative and Implementing Political Institutions in Ethiopia
}

\author{
Gudeta Kebede Asfaw \\ Governance and Development Department, Jimma University
}

\begin{abstract}
The role of political institutions could be dichotomized into two. Some of them are on the representational side of the political system (parties and parliaments). Some of them are on the implementation side of the system (the government, the police, the courts, the government media, and the civil service). The expected role of political institutions to structure politics and policy-making. In response to this concern, this paper explored the status of existed political institutions in Ethiopia. In contrast to the main roles vested in political institutions, this paper argued that these governing institutions manifested inherent institutional weakness in Ethiopia. The paper contends that there has been institutional decline and the nominal nature of the country's governing institutions. This could be demonstrated by the omnipotent executive, rubber-stamp legislature, subservient judiciary, repressive policy, and ineffective civil service of the country.
\end{abstract}

Keywords: Ethiopia, political institutions, the executive, legislative, judiciary, civil service, political parties.

DOI: $10.7176 /$ IAGS/93-02

Publication date: January $31^{\text {st }} 2022$

\section{INTRODUCTION}

Political institutions structure the politics and policy making of a given political system ${ }^{1}$. One-way political institution structure politics is constraining 'political actors by sanctioning deviation from the institutionally prescribed behavior'2. By taking this important function of political institutions as a point of inquiry, this article is attempted to give an overview of the political governance institutions of central importance in Ethiopia today. The political governance environment of the country consists of the federal government, nine regional states, and two regional administrations. The article focuses only on major governance institutions at the federal level. Likewise, in most African political systems institutional context, the nature of the current government in Ethiopia could be designated as a hybrid regime having the features of both parliamentary and presidential systems of government. However, principally its formal institutional arrangement is more in line with the parliamentary model of government. Having one typical feature of a parliamentary system, the country's institutional context exhibited a fusion of power between the legislature and the executive branches of government, and with the latter having substantial executive power. As part of the presidential system, the current constitution establishes the head of state under the office of the president having ceremonial power and functions. As an output of the existing political system of the country, the political institutions of the EPRDF regime have three types of machinery of government structure with federal executive, legislature, and judicial branches.

This paper provides an overview of not only these branches of government, but also the other public and political institutions (police, civil service, and political parties) which are categorized under-representation and implementation role of the existing political system of the country. This paper is divided into six sections. The first section deals with the omnipotent executive branch of government. The second analyzes the legislature. The third and fourth sections describe the judiciary and police respectively. The last section analyzes the civil service system of the country.

\section{OMNIPOTENT EXECUTIVE}

The federal executive is 'organized by instituting various line ministries, authorities, agencies and commissions whose roles and responsibilities are specified in Proclamation No. 41/1993 that defines the powers and duties of the central executive organs' ${ }^{3}$. As a parliamentary system, the real executive power is vested in the prime minister, who is the chief executive of the government. The prime minister is the head of government elected from the leader of the majority party in the House of Peoples' Representatives (HoPR) for five years and constitutionally. There are no term limits in his/her tenure in office. As the chief executive officer, he/she is the chairman of the Council of Ministers, the commander-in-chief of the national armed forces, as well as the head of the entire civil service. Government officials of the Council of Ministers are elected 'mostly from among members of the HoPR, with a small number appointed from outside' ${ }^{4}$ under the approval of HoPR.

In Ethiopia, the Prime Minister appoints high ranking officials of federal administration (ministers, viceministers, head of agencies and commissions) by the virtue of their political allegiance and loyalty to him. Besides, the majority of middle-level executives (head of division and department of government agencies) position at the federal and regional level of the country has been filled by political appointees of the ruling party. 
This could make the prime minister dominate the executive branch of government at both the federal and regional levels.

The prime minister is in charge of implementing socio-economic policies, controlling and supervising all the activities of the country's administrative position, preparing the national budget, and initiating legislation to be approved by the parliament. Theoretically, the office of the prime minister is responsible to the parliament and submits periodic reports on the work accomplished by the executive as well as on its plan and proposal to the parliament ${ }^{5}$. In terms of policy initiation, at a formal level, the country's legal framework allows different office-holders and institutions to initiate different draft bills-the speaker or the deputy speaker, members of parliament, legislative committees, executive bodies, the judiciary, and other government institutions accountable to HoPR. However, in present-day Ethiopia, 'enormous policy-making power...is vested in the executive ${ }^{6}$ and concerning initiating of bills there is the complete domination of the process by the Office of the Prime Minister. For instance, from 1991-2004, 498 draft bills were ratified by the transitional government council and HoPR, out of which the source of $99.4 \%$ (495) was initiated by the Prime Minister Office, whereas only $0.6 \%$ (3) draft bills were initiated by House of Federation (HoF). In this regard, in public policy making undertaking, institutionally 'the governing party... and the bureaucratic actor in Ethiopia assumed overwhelming central roles in initiating, shaping and pursuing public policies. More importantly, the executive and EPRDF were the most important actors in placing issues on the agenda, assessing alternatives, and were also in charge of implementation" ${ }^{7}$. At the helm of the executive, policy-making in Ethiopia is a highly centralized undertaking vis-à-vis the societal actor, where 'participation in the policy making process by the citizenry has been minimal, partly because government institutions had very narrow circles of policy makers that deterred participation, and also because large sectors of the public were probably politically inactive as well as inarticulate" ${ }^{8}$.

As a feature of the semi-presidential system, the current constitution of Ethiopia also recognizes the office of the president with nominal power and ceremonial functions. The president is more of a nominal executive and 'a titular head of state in Ethiopia and who is nominated by the ... [parliament] and elected in a joint session of ... [both houses of the parliament] by a two-thirds majority vote ${ }^{9}$. The nominal duties of the president include 'addressing the joint session of the parliament annually, appointing ambassadors, granting high military titles, and decorating high domestic and foreign dignitaries with medals and prizes, of course, after having been recommended by the Prime Minister' ${ }^{10}$. Unlike the Prime Minister, whose term of mandate expires after five years, the term limit of the President is for a maximum of two-six- years'. As an institutional choice of the current political actors in Ethiopia, the existing 'constitutional design for the parliament's and the executive's stay in office to be a year less than that of the president, is to establish a continuity of government and linkage between the proceeding and forthcoming terms ${ }^{11}$.

\section{RUBBER STAMP LEGISLATURE}

The federal legislature in Ethiopia is organized as a bicameral system consists of two chambers HoPR and HoF. As a representative institution, members of the first house (HoPR) are directly elected to fill 547 parliamentary seats in the legislative chamber for a five-year term from electoral districts or constituencies throughout the country, with each district or constituency having a population of $100,000^{12}$. The second chamber (HoF) is designated as Council of 'nations, nationalities, and people', and its members are elected for five years. Members of HoF are elected either by regional councils (legislatures) or through direct votes of the peoples of the regions. In terms of composition, "not only does a member represent each ethnic community in the HoF, but one additional member for every one million of its population can ...represent each ethnic community' ${ }^{13}$. The need for the second chamber in Ethiopia was based on the desire to 'symbolize ethnic representation and the embodiment of the nations, nationalities, and peoples ${ }^{14}$ which are considered as sovereign in the post-1991 new political dispensation of the country.

Constitutionally, the HoF, inter alia 'vested with powers to decide on matters of federal and regional revenue sources, litigations relating to constitutional matters (judicial review), the rights of ethnic groups to selfdetermination, and interpret the constitution' ${ }^{15}$. Regarding constitutional dispute in Ethiopia, the HoF's final decision on the matter is 'considered as a law to be applied in similar cases that arise in the future" 16 . As far as the institution of juridical review is concerned, the Ethiopian constitutional framer's policy choice or 'decision to vest the power of constitutional interpretation in a non-judicial body is unusual. Worldwide, most political systems utilize some form of judicial constitutional review; either by way of a supreme court or a constitutional court $^{17}$. Except for Finland, those countries [Bahrain, Congo, Cuba, North Korea, and Zimbabwe] having 'systems of non-judicial constitutional review do not have reputations for fostering democratic freedoms' ${ }^{\text {'18. The }}$ rationale for vesting the power of interpreting the country's constitution in the HoF, other than regular judiciary or a constitutional court, is because the framers of this constitution 'think that the new federal dispensation is the outcome of the 'coming together' of the nationalities and ... [the] Constitution is considered as the reflection of the 'free will and consent' of the nationalities... [it is considered as ] 'a political contract' and therefore only the 
authors that are the nationalities should be the ones to be vested with the power of interpreting the Constitution' 19 . In addition to this, when one can take into account the overall competencies of the HoF, unlike most other upper chambers around the world (like UK, Canada, and South Africa), in the true sense of the functions that an upper chamber is indeed called upon to perform, HoF has no power of legislation ${ }^{20}$. Put differently, the ' $\mathrm{HoF}$ is not part of the federal law-making process in Ethiopia and a federal bill does not need the consent of the HoF to become a law' ${ }^{21}$. In contrast to the HoF, the lower house is entrusted the sole power of legislation and it has a wide range of lawmaking functions in all matters assigned to the federal government.

As far as the legislature-executive interaction in the body politics of Ethiopia is concerned, the supremacy of HoPR over the executive is stipulated in the current constitution. Among other things, as the highest authority in the federal government, HoPR is 'granted the power to question the Prime Minister and other top officials of government agencies to examine both the executive's handling of its powers and discharge of its duties, taking the necessary measures should these have been missed'22. As a result of the 'winner-takes-all' character of the country's electoral and party politics, the official multiparty system of the country relegated 'into a somewhat loosely conceived "dominant one-party" political system, ${ }^{23}$, starting from 1995 the ruling EPRDF party has had an overwhelming majority of the seats in the parliament (well over 95\%). As an inherent feature of a parliamentary system, the fusion of powers between the country's legislature and the executive branch resulted in executive dominance to manage and control the parliamentary proceedings and legislative outputs effectively. This is a very common trend in many African hybrid political systems that combine the power concentrating features of the parliamentary and the presidential systems, which result in the omnipotent executive branch ${ }^{24}$. This prompts one to raise questions regarding the trend in the initiation and approval of bills in the Ethiopian parliament ${ }^{25}$.

As indicated above, the initiation of the bill is largely dominated by the executive. Whereas in approving of bills, the usual parliamentary norm in Ethiopian is that 'members of parliament support steadfastly proposed bills of the executive without much scrutiny and debate'26, and up until now 'there is no single instance when bills proposed by the executive have failed to be endorsed in parliament ${ }^{27}$. In this regard, as far as the existing parliamentary norm of the country is concerned, 'there was hardly a bill that went beyond a second reading in the HoPR, for it was certainly taken for granted that a bill would immediately be approved if it were presented by the standing committee of the HoPR for a second reading ${ }^{28}$. The Ethiopian legislature's effectiveness in exercising its oversight role in checking the performance of the executive is generally very low. For instance, according to the available data (1995-2000), during this period out of the expected 51 institutions in Ethiopia, 'less than a third of the federal executive agencies reported once during the last two years and more than half reported once during the previous two years, 29 .

Thus, one can justifiably argue that in Ethiopia's parliamentary system, the legislative body at the federal level has not been 'capable of holding the executive accountable. The executive remains unwontedly powerful with nobody to provide checks and balances'30. This state of an affair or the inherent 'incapacity of the formal political structure to check the absolute power of the chief executive' ${ }^{31}$ is an outcome of the existing 'power relations closely associated with the workings of party politics and electoral systems ${ }^{32}$. This is because almost all members of the parliament and executive belong to the ruling EPRDF, and at the same time the leader of the party is also the head of the executive, and hence the party's internal disciplinary mechanism, especially democratic centralism, does not allow members of the parliament to reject or seriously question the executive proposal. In this regard, 'instead of the parliament controlling the executive, ironically, the executive was effectively controlling the parliament in Ethiopia' ${ }^{33}$.

\section{SUBSERVIENT JUDICIARY}

The Ethiopian judiciary system consists of two parallel court systems at the federal and regional levels; each level has a three-tier structure of the courts' system. In terms of jurisdiction of power, the current Constitution of the country stipulates that the Federal Supreme Court shall have the highest and final judicial power over federal matters while the State Supreme Court shall have the highest and final judicial power over state matters. The federal judiciary in Ethiopia has a three-level hierarchy of courts: Federal Supreme Court, Federal High Court, and Federal First Instance Court. The President and Vice-President of the Federal Supreme Court are appointed by Parliament upon nomination by the Prime Minister. As indicated in Articles 16 to 18 of the Federal Courts Proclamation No. 25/1996, the President of the Federal Supreme Court has enormous power. At the federal level, 'the day-to-day operation of the courts is supervised and managed by court presidents, who therefore act both as judges and as administration officials with responsibilities and obligations towards the President of the Supreme Court' ${ }^{34}$. The rest of the judges are nominated by the Federal Judicial Administrative Council and appointed by the parliament upon the recommendation of the Prime Minister. According to the tenure of judges guaranteed in the Constitution, Article 79 (4), no judge can be removed from his duties before he reaches the retirement age determined by law' (Art. 79 (4)). In line with this constitutional rule, judges can be removed from their duties for reasons of 'violation of disciplinary rules or on grounds of gross incompetence or inefficiency or if found unfit to 
operate due to ill health. In all cases, the removal has to be sanctioned by a majority vote of the HPR in the case of federal judges and by the state council in the case of state judges ${ }^{35}$.

Concerning formal recognition of institutional rules protecting courts and judges from outside influence in Ethiopia, articles 78(1) and 79(2) of the Constitution stipulate the independence of the judiciary and they provide that "courts of any level shall be free from any interference of influence of any governmental body, governmental official or any other sources respectively. In addition to this, paragraph three of the same article also guarantees the personal independence of judges providing that judges shall exercise their functions in full independence and shall be directed solely by the law. Despite the country's constitutional guarantee of personal and institutional independence of judges in the administration of justice; however, 'in practice, it is subject to enormous political, public, and mass media pressure, which compromises its neutrality'36. As Paulos ${ }^{37}$ (2001a, 89) summarizes, in most cases in Ethiopia, 'freedom of judiciary is not respected. Appointment and removal of judges have been done arbitrarily; political factors are the overriding technical and procedural conditions that are considered in the process. This is against the conditions stipulated in the federal constitution concerning the removal of judges. However, in most cases, judges have been removed by executive organs without due consideration of relevant procedures to be followed for such purposes'.

As with the other institutions of governance, generally, the judiciary is expected to 'assume a key role in the process of ensuring democracy and the rule of law. The judicial branch of the state is normally charged with the task of ensuring the protection of rights and freedoms recognized by the constitution and subsequent legal sources ${ }^{38}$. As part of the check and balance mechanism, this institution is also 'expected to check whether acts of the executive are in line with the principal legislation issued by parliament and whether the executive is acting within the framework of the law'39. To fulfill these constitutional vested roles, the efficacy of 'the judiciary depends ultimately on its level of capacity, which in turn depends on the relative strengths of the configuration of the appropriate capacity ingredients for the judiciary, as well as the environment in which the institution functions ${ }^{40}$. In this vein, when one can examine the judiciary in Ethiopia and its role as an instrument for horizontal accountability, one could encounter many salient features; 'first and foremost the judiciary never had a separate existence of its own as an [independent] institution. It was subject to all kinds of pressures from the other branches. Thus, external pressure on the judiciary has deep roots and is not without some hangovers on the new federal judiciary. Administrators at the state level, even today, think that it is natural to order the judge or at times even close benches at the lower level of administration'41. Second, the judiciary in Ethiopia "never survived the regime it established. It was no surprise to see every new regime setting up its version of the judiciary that suits its mission. It was never designed to be an institution as the third branch of the government in the real sense' of the term ${ }^{42}$. This is because, "Ethiopia's judicial system is generally characterized by a fusion, not separation, of administrative and judicial functions in one organ. In historic Ethiopia, adjudication of cases has formed part of public administration. One finds a merger of functions, with the adjudication of cases being considered by executive' as a principal function of its own at the expense of judiciary' ${ }^{3}$.

In addition to the aforementioned, lack of separate institutional existence of the judiciary in Ethiopia, currently, the EPRDF's government distrust towards the judiciary is also visible on two counts. First, as far as the adjudication of constitutional matters is concerned, the judiciary in Ethiopia lacks the power to interpret the constitution. Second, there is a 'growing exclusion of courts through jurisdictional ouster clauses concerning issues...considered politically or economically sensitive' ${ }^{44}$. The authority of the judiciary has come 'under further attack through the tendency of the legislature to issue ouster clauses' 45 'chipping away of the powers of the judiciary and given them to the other governmental institutions to exercise the power to be 'judges, jury and executioner' all in one ${ }^{46}$. This was manifested in the case of proclamations of the Commercial Bank of Ethiopia, Agency for Government Houses in Ethiopia, Charities and Societies, the amended Electoral Law of Ethiopia, and the Ethiopian Revenues and Customs Authority establishment. According to Proclamation 97/1998, banks are empowered to foreclose the property of defaulting debtors. In the same vein, the AGHE also is 'empowered to give and execute expulsion orders to tenants of government houses and order the police force to this effect if it thinks there is a breach of contract or the tenant is an illegal occupant ${ }^{47}$.

According to the Electoral Law of Ethiopia Amendment Proclamation 532/2007, art 79(1), the National Electoral Board (NEB) 'is authorized to do what it wishes about granting or refusing license for CSOs to observe elections or educate voters without the possibility of appeal to ordinary courts ${ }^{48}$. Before this proclamation, the NEB's decision on this matter was subject to judicial review, and particularly NEB's decision to prevent several CSOs from observing the 2005 elections was overturned by the Federal Supreme Court decision ${ }^{49}$. Last but not least, the CSO Proclamation 621/2009 does not guarantee the right to appeal against the decisions on the Charities and Societies Agency to CSOs considered non-Ethiopian or 'foreign' 50 . The ERCA Proclamation No. $587 / 2008$, concerning disciplinary matters, allows the Director-General of the authority under consideration to dismiss the employee who is suspected of corruption 'without the need of going through the whole procedure of taking disciplinary measures, and what makes it worse is that an employee, dismissed under these circumstances,

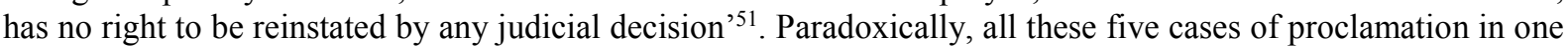


way or another grossly violate art 78(4) of the incumbent constitution that stipulates that 'special or ad hoc courts will never be established that will take judicial powers away from the courts or institutions legally empowered to exercise judicial functions and do not follow the prescribed procedure'. Thanks to the current oneparty dominated legislature in the country, where the executive easily managed to have such kinds of arbitrary rulemaking at the expense of the judiciary who denied judicial control over delegated legislation in Ethiopia. The status of the judiciary is critically precarious, and 'courts have therefore been deprived of one of their essential roles, ensuring that the executive operates within the parameters set by the law' ${ }^{52}$. Suffice it to say here that the role of the judiciary tends to be much less significant in the body politics of Ethiopia like most Sub-Saharan African courts do.

\section{REPRESSIVE POLICE}

As part of the federal state structure, the formal police system in Ethiopia adheres to the broader national structures of ethnic federalism and currently operating at federal and regional levels. The policing structure of the country consists of federal police and nine regional police forces. The chartered cities of Addis Ababa and Dire Dawa also have a police force of their own delegated by the federal police $(\operatorname{art} 24(1))^{53}$. In terms of institutional setup, the federal police in Ethiopia are organized as a commission entity. The federal police are directly accountable to the Minister of Federal Affairs for management issues. However, it operates independently when it comes to operational police work. As far as the power and functions of the Ethiopian federal police are concerned, they are 'mainly responsible for the prevention and investigation of crimes that relate to state security, including transnational crimes. They play a coordinating role at the national level and are responsible for the development of national policing standards and new initiatives such as community policing. Also, they provide professional and technical advice, support, and training to the regional police forces. With the investigation of federal crimes committed within regions, the federal police have delegated powers to the regional police, though they also provide support in the investigation of federal crimes, especially in the case of complex investigations, when requested to do so, ${ }^{54}$.

When one can spot police-citizens relation in Sub-Saharan Africa, 'many Africans have entirely negative perceptions of the police. In many countries, members of the police are ineffective, unprofessional, corrupt, and even predatory. Their primary interest is in protecting the government in power rather than serving the public. They are often sources of insecurity rather than providers of security-people tend to avoid them, instead of seeking out their service, in the event of trouble. For other African citizens, particularly those living outside urban areas, the police are conspicuous by their absence' 55 in rural areas. This state of affairs is also true for citizens in Ethiopia, where 'the police and the security forces remain 'politicized instruments of control'. They form part of the state machinery of repression and are rarely seen as 'friends and helpers' or guardians of public order, particularly in the rural areas, away from paved roads and urban centers' ${ }^{56}$.

Toggia's article on how the three successive regimes in Ethiopia applied their power during periods of state of emergence ${ }^{57}$ indicates that 'they resorted to similar techniques of extensive and intensive control by the police,..., to reproduce and reassert the prevailing power relations under the guise of maintaining public order ${ }^{58}$. He stresses that in the state of crisis, the 'main function of police in maintaining 'law and order' is to integrate laws into the state's order - that is, a state order established under 'a rule by law', not under 'the rule of law's9. $\mathrm{He}$ asserts that 'the Ethiopian police have unlimited and unqualified powers that encompass enforcement, prosecution, and punishment' ${ }^{60}$. Toggia further maintains 'within the general and conventional police functions of maintaining law and order, Ethiopian police have assumed unique functions and an exceptional role to legitimize and stabilize state power, albeit with excessive use of force during times of state crisis ${ }^{\prime 61}$.

As pointed out in a comprehensive justice system reform baseline report, it is 'common knowledge in Ethiopia that the police wrestle with a poor image' ${ }^{62}$. The report also indicates that a large number of police officers were dismissed because of a lack of police integrity and conduct, particularly some police have been also charged with corruption offenses. As indicated above, by law, the police forces have been demilitarized and military ranking has been abandoned. Paradoxically, 'the mentality of police agents [in Ethiopia] is still not completely demilitarized. An example is that the police manifestly and excessively carry heavy weapons, even when on ordinary patrol. This maintains the negative image of the police as a service of power and oppression rather than a public service-oriented body' ${ }^{63}$.

Regarding the actual effectiveness of crime investigation, the 'technical investigation capacity of the Ethiopian police has been very weak as it was not supported by the sufficient number of well-trained investigators and scientific investigation facilities ${ }^{\prime 64}$. It is obvious that weak investigation skills lead to lengthy investigations and often inadequate evidence for the courts; for instance, 'at the federal level, the conviction rate of the prosecution in 2010 was $47 \%$, whereas the conviction rate for crimes of violence against women and children was only $28.7 \%{ }^{65}$. In a given justice system, police and prosecution service are expected to work together in investigating, prosecuting, and thus preventing crime. In Ethiopia, even if article 7(2) of Federal Police Commission Proclamation 313/2003 provides the Public Prosecution Service (PPS) with the power to 
order the police regarding the investigation of crimes; the PPS does not play a leading role in the criminal investigation performed by the police. This faulty practice of no control on or supervision of policy work, 'made the police an autonomous institution that is independently operating in a criminal investigation without a competent criminal authority (by law it is the PPS) executing control and supervision over it. It is very worrisome that in such a case, the police may perform activities that could be inconsistent with the rule of law without being corrected. It is also a big concern that the PPS and the police do not work with each other but rather next to each other'66.

About the integrity of the criminal justice system, police 'must never act in a way that may prejudice, or be seen to affect the impartiality of the judiciary... [They] are subject to the judiciary in judicial decisions, which they must scrupulously respect and often implement ${ }^{967}$. However, as a part of the informal police culture ${ }^{68}$ in Ethiopia, 'police are perceived as a law unto themselves and do not feel bound by court orders or prosecution directions. Examples of this may be found in the area of remand. Police may not always respect release orders issued by a court ${ }^{\prime 69}$. Besides, concerning the relation of the police with the prosecution, 'Ethiopian police do not seem to take the prosecution seriously when it comes to pre-trial investigation and in cases of request for further investigation by the prosecution. This has led to a huge backlog but also to flagrant breaches of the Ethiopian laws and abuses of fundamental human rights of suspects who have been kept in (remand) custody for years, ${ }^{70}$.

Policing in a democratic society entails that "police are accountable not only to the state but also vis-à-vis the public in such a society and their efficiency is to a large extent depending on public support. In this respect, the social function and the public service side of the police are important also for the carrying out of law enforcement ${ }^{71}$. As opposed to this, concerning the protection of human rights of political opponents of the regime, issues such as police brutality, illegal detention including the holding of political prisoners without bail, inhumane prison conditions, and the use of torture are common themes in the police system in Ethiopia.

\section{THE CIVIL SERVICE SYSTEM}

The civil service institution or the bureaucracy of a given country could play a crucial role in 'the day-to-day processes of decision making and especially the implementation of public policy ${ }^{72}$. Usually, the civil service system is considered as 'the operational arm of the government, charged with providing analysis, making recommendations, and implementing the administration of public policy ${ }^{73}$. Organizationally, the Ethiopian civil service has a dual system of a structure at a federal and regional level in the post-1991 period. At the regional level, regional state governments have their own independent civil service commissions. At the federal level, the Ethiopian civil service constitutes all those employees on permanent posts within the Federal Government institutions and does not include government officials with the rank of state minister, deputy director-general and their equivalents, members of the House of Peoples' Representatives and the House of Federation, Federal Judges and Prosecutors, members of the Armed Forces and the Federal Police and employees excluded by other appropriate laws $\left(\operatorname{art}^{74} .2(1)\right)$.

According to $\mathrm{MCB}^{75}$, the executive branch in Ethiopia consists of 17 Ministries, 10 Authorities, 19 Agencies, 12 Offices, 8 Institutes, and 52 different institutions as of August 2009. In terms of growth, the size of the total civil service in Ethiopia rose from 336,427 in the post-1991 period to 926,716 in 2010 , an overall increase of $61.7 \%$. The share of female and male employees currently stands at $31.1 \%$ and $68.9 \%$ respectively. The rationale behind the steady growth of the civil service in the post-1991 period is associated with the 'formal devolution of power from the center to sub-national levels since the 1992 reorganization of regional administration has entailed its expansion on a progressively increasing ${ }^{\text {} 76}$. Considering the country's population of approximately 82 million and compared to other countries like Egypt (7.5) and Thailand (3.6) having a population size of 80 and 65 million respectively, however, the size of Ethiopian civil service is relatively smaller (1.13). This means that one civil servant provides service to 100 people in Ethiopia.

Before the 1991 period, the Ethiopian civil service exhibited institutional shortcomings of 'duplication and fragmentation of public functions and the downplaying of merit and professionalism... It [was] also characterized by the centralization of administration in addition to the increase of corruption, inefficient service delivery, and the routine neglect of the due process of law in matters of public concern'77. When it came to power in 1991, the incumbent government in Ethiopia 'inherited a highly centralized and control-oriented civil service ... [that] lacked autonomy while accountability to citizens was weak ${ }^{78}$. Because of this institutional incapability; logically, the transition from a socialist (Dergue regime) to a federal system of the country necessitated a reorientation of the civil service towards a more service-oriented public administration ${ }^{79}$. Given the significant role the civil service plays in the socio-economic development effort of the country, starting from 1994, the government of Ethiopia has embarked on a comprehensive civil service reform program designed to improve performance and strengthen accountability and transparency ${ }^{80}$.

The leading vision behind civil service reform in Ethiopia is the need 'to build a civil service that helps achieve government development policies and programs, promote principles of federalism and democracy; serves the citizenry honestly and diligently, is transparent and responsive, is accountable to elected 
representatives of the people, and is imbued with professional ethics ${ }^{81}$. The result of this reform has been mixed. On the one hand, some of the successes are associated with improving service delivery. These include the 'setting up information desks, wearing names budges, posting direction pointers, arranging complaints handling mechanisms, stipulating service standers as well as the changes introduced by reengineering processes, and undertaking quick wins ${ }^{92}$. In connection to service delivery, the 'reform efforts brought about a great deal of citizen awareness of their rights to get public goods or services from public institutions. As a result, citizens are increasingly demanding that the public sector provide better service and become transparent and accountable and, in turn, this is expected to create more pressure on public institutions to further improve their public service ${ }^{98}$. On the other hand, 'the basic reasons behind the weaknesses of the civil service seem not to have been properly articulated and diagnosed. It seems that the reform measures are introduced without giving due attention to the country's administrative history, existing political reality, administrative capacity, and economic structure. The prescriptions are mere transplantations and are impositions made without understanding the context ${ }^{84}$.

Overall, the low-efficiency level of government service delivery has been persisted in Ethiopia since the problems are fundamental and systemic ${ }^{85}$. The civil service system in Ethiopia has institutional and capacity weaknesses. The variety of factors associated with this dismal and bleak scenario are summarized as follows: 'poor civil service pay and compensation system, the undue share of the posts being political appointments rather than career posts, a substandard training system, lack of trust, respect and confidence by the politicians of the career civil service ${ }^{96}$

In the essence of efficient and effective service delivery to the public, 'the good governance principle of responsiveness requires the promotion of a professional civil service that is not only capable but also characteristically representative of the population"87. As opposed to this, currently in Ethiopia, 'government employment...has the added humiliating aspect as there is no meaningful career ladder that one aspires to base on qualification and competence. Unlike in the established democracies, government bureaucracies are filled at all levels on clientelist considerations whereby loyal cadres or supporters of the ruling party and the "big man" president are given administrative positions despite their manifest incompetence over government employees who are far superior in their ability ${ }^{88}$.

\section{CONCLUSION}

The recent state-building in Ethiopia in which the current representative and implementing institutions have emerged after 1991. The existed governing institutional structure conditioned in institutionalizing the second republic of the country. The representational side of the political institutions includes political parties and legislature, whereas the implementation side of the system is composed of the executive, the police, the courts, and the civil service. This paper attempted to draw attention to the nominal tendencies of political institutions in Ethiopia. The paper conceded that political institutions in Ethiopia are under the discretion of the government in power. They are not exogenous constraints against the authoritarian incumbent government. The defining features of the country's institutional landscape reveal an omnipotent executive, rubber-stamp legislature, subservient judiciary, repressive police, and ineffective civil service.

\section{Notes}

1. Keman and Woldendorp, Handbook of Research Methods.

2. Armingeon, 'Political institutions', 235.

3. Kassahun, 'The Ethiopian Transition', 5.

4. Asmelash, 'Ethiopia', 233.

5. Ibid.

6. Mulugeta and Cloete, 'Public Policy-Making', 149.

7. Ibid., 142.

8. Ibid.

9. Asmelash, 'Ethiopia', 233.

10. Mulugeta and Cloete, 'Public Policy-Making',149.

11. Ibid.

12. Ibid.

13. Ibid., 147.

14. Ibid.

15. Kassahun, 'The Ethiopian Transition', 6.

16. Mgbako et al., 'Silencing the Ethiopian Courts', 274.

17. Ibid., 278.

18. Ibid.

19. Assefa, 'Constitutional Adjudication', 10.

20. Mulugeta and Cloete, 'Public Policy-Making'. 
21. Assefa, 'Ethiopia's Experiment', 448-449.

22. Pennington, 'The Bureaucracy', 147.

23. Kassahun, 'Parliament', 176.

24. Cranenburgh, 'Democracy promotion'.

25. Kassahun, 'Parliament'.

26. Ibid., 177.

27. Kassahun, 'The Ethiopian Transition', 5.

28. Mulugeta and Cloete, 'Public Policy-Making',152.

29. Paulos, What One Hand Giveth, 307.

30. Ibid., 321.

31. Ibid.

32. Kassahun, 'Parliament', 178.

33. Mulugeta and Cloete, 'Public Policy-Making',151.

34. MCB, Ethiopia, 160.

35. ADB and ADF, 'Federal Democratic Republic', 11.

36. Blackburn and Matthews, 'Crime and punishment',172.

37. Paulos, 'Reflections', 89.

38. Getahun, 'Mechanisms', 98.

39. Assefa, 'Separation of powers', 702.

40. UNECA, African Governance, 128.

41. Assefa, 'Constitutional Adjudication',13.

42. Ibid.

43. Assefa, 'Separation of powers',703.

44. Adem, 'From the 'TPLF Constitution',78.

45. Assefa, 'Separation of powers',706.

46. Gudeta, 'Political Corruption', 265.

47. Assefa, 'Separation of powers', 707.

48. Adem, 'From the 'TPLF Constitution', 78.

49. ADB and ADF, 'Federal Democratic Republic'.

50. Adem, 'From the 'TPLF Constitution'.

51. Aron and Abdulatif, 'Administrative Rulemaking', 25.

52. Adem, 'From the 'TPLF Constitution', 79.

53. It refers to the Federal Police Commission Proclamation, 313/2003.

54. Baker, 'Hybridity in Policing', 301.

55. Downie, Building Police Institutions, 1.

56. Vaughan and Tronvoll, The Culture of Power, 102.

57. It refers to serious challenges and resistance to their state powers.

58. Toggia, 'The State of Emergency',122.

59. Ibid., 114.

60. Ibid., 113.

61. Ibid., 114.

62. MCB, Ethiopia, 188.

63. Ibid., 189.

64. Mandefrot, 'A Review of the Ethiopian Justice System',435.

65. Baker, 'Hybridity in Policing', 311.

66. MCB, Ethiopia, 183.

67. Ibid., 472.

68. It refers to the values, norms, perspectives, and craft rules that inform police conduct (Reiner, 1992).

69. MCB, Ethiopia, 248.

70. Ibid., 193.

71. Ibid., 465.

72. Pennington, 'The Bureaucracy', 146.

73. Atikilt, 'The Role of the Federal Civil service', 90.

74. It refers to article 2(1) of Federal Civil Service Proclamation No. 515/2007.

75. MCB, Ethiopia.

76. Kassahun, 'The Ethiopian Transition', 7.

77. Getachew and Common, 'Public Sector Capacity', 368.

78. ADB and ADF, 'Federal Democratic Republic', 4.

79. Ibid. 
80. Ibid.

81. MCB, Ethiopia, 3

82. Mesfin, 'The Ethiopian Civil Service Reform', 406.

83. Solomon, 'Civil Service Reform', 242.

84. Paulos, 'The Challenges of the Civil Service', 21.

85. Berhanu and Vogel, 'Bureaucratic Neutrality'.

86. Paulos, 'The Challenges of the Civil Service', 21.

87. Berhanu and Vogel, 'Bureaucratic Neutrality', 207.

88. Schneider and Berhanu, 'Democracy', 240.

\section{REFERENCES}

Aalen, Lovis. 'Ethiopia After Meles: Stability for How Long?' Current History 113, no. 763 (2014):192-196.

Adem, Kassie Abebe. 'From the 'TPLF Constitution' to the 'Constitution of the People of Ethiopia': Constitutionalism and Proposals for Constitutional Reform.' In Constitutionalism and Democratic Governance in Africa: Contemporary perspectives from Sub-Saharan Africa, edited by M. Kiwinda Mbondenyi and T. Ojienda, 51-87. Cape Town: Pretoria University Law Press, 2013.

Africa Development Bank and Africa Development Forum (ADB and ADF). 2009. 'Federal Democratic Republic of Ethiopia: Country Governance Profile.', ADB and ADF., 2009. http://www.afdb.org/.../Ethiopia\%20-\%20Country\%20Governance\%20Profile (accesed 02 February, 2013).

Armingeon, Klaus. 'Political institutions.'In Handbook of Research Methods and Applications in Political Science, edited by Hans Keman and Jaap J., Woldendorp, 234-247. Cheltenham: Edward Elgar Publishing, 2016.

Aron, Degol and Kedir, Abdulatif. 'Administrative Rulemaking in Ethiopia: Normative and Institutional Framework.'Mizan Law Review 7, no. 1 (2013): 1-28.

Asmelash, Beyene. 'Ethiopia.' In Public Administration in Africa: Main Issues and Selected Country Studies, edited by L Adamolekun, 227-249. Colorado: Westview Press, 1999.

Assefa, Fiseha. 'Ethiopia's Experiment in Accommodating Diversity: 20 Years' Balance Sheet.' Regional and Federal Studies 22, (2012): 435-473.

Assefa, Fiseha. 'Constitutional Adjudication in Ethiopia: Exploring the Experience of the House of Federation (HoF).' Mizan Law Review 1, no. 1 (2007): 1-35.

Assefa, Fiseha. 'Separation of powers and its implications for the judiciary in Ethiopia.' Journal of Eastern African Studies 5, (2011): 702-715.

Atikilt, Assefa. 'The Role of the Federal Civil service in the Transition to Good governance and Market Oriented Economy in Ethiopia.' In The Role of Professional Management in the Transition to Good Governance and Market Oriented Economy in Ethiopia: Proceedings of the Fourth Annual Conference on Management in Ethiopia, edited by M., Ayenew and B. Alemahu, 77-106. Addis Ababa: EMPA, 1999.

Baker, Bruce. 'Hybridity in Policing: The Case of Ethiopia.' The Journal of Legal Pluralism and Unofficial Law 45, no. 3 (2013): 296-313.

Bakran, Joel. D. 'Legislatures on the Rise?' In Democratization in Africa: Progress and Retreat, edited by L. Diamond and M.F. Plattner, 33-46. Baltimore: Johns Hopkins University Press, 2010.

Berhanu, Mengistu, and Elizabeth, Vogel. 'Bureaucratic Neutrality among Competing Bureaucratic Values in an Ethnic Federalism: The Case of Ethiopia.'Public Administration Review, (2006): 205-216.

Blackburn, Ashley. G., and Meredith, Matthews. 'Crime and punishment in Ethiopia: A Country Profile.' International Journal of Comparative and Applied Criminal Justice 35, no. 2 (2011): 167-181.

Blake, Charles. H. 'Public Attitude towards Corruption.' In Corruption and Democracy in Latin America, edited by Stephen D. Morris and Charles H. Blake, 94-107. Pittsburgh: University of Pittsburgh Press, 2009.

Cranenburgh, Oda. Van. 'Democracy promotion in Africa: The Institutional Context.' In Democratization in Africa: Challenges and Prospects, edited by G. Crawford and G. Lynch, 169-187. Oxon: Routledge, 2012.

Downie, Richard. Building Police Institutions in the Fragile States: Case Studies From Africa. Washington, DC: Centre for Strategic \& International Studies (CSIS), 2013.

Getachew, Hailemariam M. and Richard, Common. 'Public Sector Capacity Reform in Ethiopia: A Tale of Success in Two Ministries?' Public Administration and Development 27(2007): 367-380.

Getahun, Kassa. 'Mechanisms of Constitutional Control: a Preliminary Observation of the Ethiopian System.' Afrika Focus 20, no. 1-2 (2007): 75-104.

Grekou, Douwere. An Empirical Investigation of Ethnicity and Trust in Africa, 2011. HYPERLINK "http://www.publish.uwo.ca//dgrekou/research/EthncityTrustDraft.pdf" http://www.publish.uwo.ca// dgrekou/research/EthncityTrustDraft.pdf (accessed October6, 2013).

Gudeta, Kebede. 'Political Corruption: Political and Economic State Capture in Ethiopia.' European Scientific Journal 9, no.35 (2013): 250-279. 
Gudeta, Kebede, and Kassa Alemu. 'Ethiopian Opposition Political Parties in the post-1991 Political Structure.' International Journal of Current Research 6, no. 01 (2014): 4784-4799.

Human Right Watch (HRW). 'They Want a Confession' Torture and Ill-Treatment in Ethiopia's Maekelawi Police Station., 2013. HYPERLINK "https://www.hrw.org/report/2013/10/17thet-want-confession/tortureand-ill-treatment-ethiopians-maekelawi-police-station" https://www.hrw.org/report/2013/10/17thet-wantconfession/torture-and-ill-treatment-ethiopians-maekelawi-police-station (accesed 24 December, 2013)

Kasahun, Woldemariam. Myths and Realities in the Distribution of Socioeconomic Resources and Political Power in Ethiopia. Lanham: University Press of America, 2006.

Kassahun, Berhanu. 'Ethiopia: Beleaguered Opposition under a Dominant Party System.' Conference on Legitimacy of Power - Possibilities of Opposition, May 30th - June 1st, Jinja Nile Resort, Kampala, 2011.

Kassahun, Berhanu. 'Parliament and the Dominant Party System in Ethiopia.' In African Parliaments: Between Governance and Government, edited by M. A. Mohamed Salih, 162-182. New York: Palgrave Macmillan, 2005

Kassahun, Berhanu. 'The Ethiopian Transition in Regional Perspective: Election processes, Liberation movements and Democratic change in Africa.' Conference on Electoral Power, Political Parties and Liberation Movements, Maputo, April 8th-11th, 2010, 2011.

Keman, Hans, and Jaap J. Woldendorp. Handbook of Research Methods and Applications in Political Science. Cheltenham: Edward Elgar Publishing Limited, 2016.

Mandefrot, Belay. 'A Review of the Ethiopian Justice System Reform Program.' In Digest of Ethiopia's National Policies, Strategies, and Programs, edited by Assefa Taye, 419-450. Addis Ababa: Forum for Social Studies, 2008

Mesfin, Taffesse. 'The Ethiopian Civil Service Reform Program.' In Digest of Ethiopia's National Policies, Strategies, and Programs, edited by Aseffa Taye, 374-417. Addis Ababa: FSS, 2008

Mgbako, Chi; Braaschy, Sarah, Degolz, Aron, Morgan, Melisa; Segurayy, Felice; Teramed, Tezerazz. 'Silencing the Ethiopian Courts: NonJudicial Constitutional Review and its Impact on Human Rights.' Fordham International Law Journal 32, no.1 (2008): 259-297.

Ministry of Capacity Building (MCB). Ethiopia - Civil Service Reform Programme. Addis Ababa: MCB, 2009.

Mulugeta, Abebe and Cloete, Fanie. 'Public Policy-Making in Contemporary Ethiopia: An Anatomy of Institutions, Roles and Leverage, 1991-2004.' African Insight 36, no. 3 (2006): 141-159.

Paulos, Chaine. 'Reflections on the Concept of Good Governance and its Impact on the Ethiopia Context.' In Proceedings: Governance and Sustainable Development: Promoting Collaborative Partnerships, edited by M. M. Berhanu and E. Vogel, 82-91. Virginia: Old Dominion University, 2001a

Paulos, Chanie. 'The Challenges of the Civil Service Reform in Ethiopia: Initial Observations.' Eastern Africa Social Science Research Review (EASSRR) 17, no, 1 (2001b): 79-102.

Paulos, Chanie. What One Hand Giveth, the Other Hand Taketh Away: Ethiopia's post -1991 Decentralization Reform under Neo-patrimonialism. . Maastricht: Shaker Publishing BV., 2007.

Pennington, Mark. 'The Bureaucracy.' In Comparative Politics: Explaining Democratic Systems, edited by J. J. Bara and M. Pennington, 145-173. London: SAGE Publications Ltd, 2009.

Reiner, Robert. The Politics of the Police. 2nd. Hemel Hempstead: Harvester Wheatsheaf, 1992.

Schneider, Geoffrey, and Nega Berhanu. 'Democracy, Development, and Comparative Institutional Advantage in Africa.' Forum for Social Economics 42, no. 2-3 (2013): 231-247.

Solomon, Markos. 'Civil Service Reform in Ethiopia: Issues, Lessons, and Future Directions.' International Journal of Public Administration 36, (2013): 235-247.

Sun, Ivan, Rong Hu, and Yuning Wu. 'Social capital, political participation, and trust in the police in urban China.' Australian \& New Zealand Journal of Criminology 45, no. 1 (2012): 87-105.

Toggia, Pietro S. 'The State of Emergency: Police and Carceral Regimes in Modern Ethiopia.' Journal of Developing Societies 24, no. 2 (2008): 107-124.

United Nations Economic Commission for Africa (UNECA). African Governance Report 2005. Addis Ababa: Economic Commission for Africa, 2005.

Vaughan, Sarak, and Kjetil Tronvoll. The Culture of Power in contemporary Ethiopia Political Life. Stockholm: Sida, 2003. 